\title{
Training and Development of the Human Resource in Institutes of Consecrated Life: A Case of Tangaza University College (TUC) and Marist International University College (MIUC)
}

\author{
Okello Jacklyne Alari, \\ Registrar Academic, Marist International University College, Kenya
}

\begin{abstract}
This study focuses on training and development of the human resource in institutes of consecrated life; a case of Tangaza University College (TUC) and Marist International University College (MIUC). Institutions and organizations exist to achieve certain goals and objectives. These goals and objectives can be successfully achieved through the human resource. However, the human resource must have the right skills and continuously polish their skills. The human resource that is the centre of interest in this study is the consecrated men and women who are members of the institutes of consecrated life in TUC and MIUC and their leadership. Njino (2009) strongly argues that the Church has enormous human resource but at times this resource is underutilized and its abilities and potential are unexploited or unrecognized. This was the motivation and driving factor for this study.

The researcher carried out a survey. The specific method employed was descriptive survey design. The target population for the study was all professed members of institutes of consecrated life both men and women with their leadership. The study was developed by integrating interactive shared experiences of men and women religious. These are presented as cases within the different chapters. As a result the researcher only used questionnaires that contained both closed ended and open ended questions in data collection. A total of 242 individual members and 20 members of the different leadership categories of institutes of consecrated life participated in the study.

The findings reveal that availability of training policies is dependent on the category of institutes of consecrated life. Majority of the respondents indicated that professional training of members was not a priority for the leadership of the institutes of consecrated life. Work allotment entirely depends on the needs of the individual institute of consecrated life. The researcher recommends that more emphasis is to be put in the training and development of the human resource in institutes of consecrated life. This is because it shall ensure sustainability of the institute.
\end{abstract}

Key words: training, development, human resource, institutes of consecrated life

\subsection{Introduction}

Boxall (2014) stresses that people are not 'human resources' they possess the human resources, these are the overt talents and underlying characteristics that distinguish us as a species, and which account for our impacts on the planet. Individuals, organizations, human society, at national and global levels, need the wise, sustainable use of the human resources. At the highest level of human society, the goal before us is to create the conditions that enable all people to explore their potential and to do so in ways that are sustainable across generations.

Human resources should therefore be understood as the intrinsic resources, that what we possess as human beings, which we can apply to the various tasks of our lives, both in workplaces and in activities such as child-raising, recreational leisure and community service (Boxall, 2013). It is the personnel that make up the organization. In this study, they are the women and men religious. It starts from the person that does the sweeping and cleaning to the executive of the organization (Njino, 2009). All these people are valuable because of their own capacities, without them, there will result a gap in the smooth function of the organization. 
According to Okumbe (2001) the development of a motivated human resource is the single most important factor in the achievement of a wholesome organizational effectiveness. Therefore, the leadership of institutes of consecrated life are to nurture, train and develop their subjects to see the world in their lenses. This is because like any other organization, institutes of consecrated life need human resources that work hard, think creatively and perform excellently. Aspects that will enable the institutes of consecrated life flourish amidst the enormous challenges facing them in the present world.

D'Souza (2014) points out that to measure the success of any organization there is need of asking whether they have achieved their purpose. This is because organizations can effectively achieve their needs through the human resources. Human capabilities are critical to conceiving, growing, renewing organizations, and inevitably make organizations somewhat distinctive. Therefore, acquisition, prioritization, allocation, utilization, evaluation encompassed with encouraging, nurturing of the human resource in a timely and meaningful manner are required.

\subsection{Statement of the Problem}

There is competition from all corners; everybody seems to be doing all that the institutes of consecrated life are doing. The apostolic demands have changed; the pastoral ministry, social work, other works demand academic qualifications and good experience. As Dessler (2003) emphasizes that in today's high-performing organizations, trained and committed employees are the firm's competitive key. This in essence is the scenario that ought to be reflected in the institutes of consecrated life. Realizing that the institutes like other organizations have goals and objectives that should be achieved, the leadership is expected to drive the members towards the achievement putting in mind that the very success of an institution or its failure is depended on the human effort, and the personality, desires and ambitions of each individual member (Waweru, 2007) thus the need for training and development of the members of the institute.

\subsection{Research Questions}

The study was guided by the following research questions:

1. Are there training and development policies of the human resource in institutes of consecrated life?

2. How effective is the selection and placement of human resource by the leadership in institutes of consecrated life?

3. Which practical motivational approaches are used by the leadership to support the human resource in institutes of consecrated life?

4. How is the human potential harnessed for sustainable development in institutes of consecrated life?

\subsection{Hypothesis}

The following null hypotheses were tested.

$\mathrm{H}_{01:}$ There is no significant relationship between category of the institute and commissioning of members by the leadership in the light of the individual's ability and talent.

$\mathrm{H}_{02}$ : There is no significant relationship between category of the institute and commissioning of members by the leadership in the light of the individual's ability and talent.

$\mathrm{H}_{03}$ : There is no significant relationship between category of the institute and practical motivational approaches used by the leadership in institutes of consecrated life.

\subsection{Design and Overview of the Study}

The study focuses on training and development of the human resource in institutes of consecrated life, a case of TUC and MIUC. Tangaza - Theological Centre of Religious begun with a group of students on 25 August 1986. Twenty students came from seven countries and from three religious congregations (Consolata Fathers, Salesians of Don Bosco and the Congregation of the Holy Spirit). TUC is recognized as a constituent College of CUEA. While remaining administratively autonomous, Tangaza College is an integral part of the main University (CUEA) for academic purposes. Over the years a number of Institutes have been affiliated to the College or have been established as integrated Institutes of the College. TUC is owned by 22 
member religious congregations (institutes of consecrated life) making its students population to largely come from institutes of consecrated life. TUC has a total of 285 institutes of consecrated life.

MIUC began in 1986 as Marist International Centre (MIC), as a scholastic ate for the Marist brothers and other religious institutes offering an ecclesiastical degree, Bachelor of Religious Studies with Education. In May 2002 MIC was officially recognized as a Constituent College of the CUEA which was granted a charter by the Commission for Higher Education (CHE) in 1992. This relationship is governed by the terms of Convention for the Constituent Colleges of the CUEA, 1997. MIC was thereafter renamed Marist International College in 2006 and the Marist brothers opened doors for admission of the lay students. In September, 2011, Marist International College was officially upgraded and gazetted by the Kenya Government as MIUC. Although MIUC is a Constituent College of the CUEA, just like TUC it is administratively autonomous but is an integral part of CUEA for academic purposes. MIUC is owned by the Conference of Major Superiors of the Marist Brothers in Africa and Madagascar. The Marist Congregation dedicates itself to the education of young people in primary, secondary and tertiary educational centers and works for the education of youth, in and outside mainstream educational institutions. MIUC is committed to Marist Educational values of Presence, Simplicity, Family Spirit, Love for Work and In the Way of Mary. MIUC has a total of 14 institutes of consecrated life, the number keeps on changing depending on the enrolment.

This study was delimited to all consecrated men, women and priests who are members of the institutes of consecrated life and their leadership at TUC and MIUC. The researcher carried out a survey. Data was collected using both primary and secondary sources. The primary sources used for collection of data were questionnaires that had both open and closed ended questions. However, for the development of the literature review both primary and secondary sources were used as captured in the study. The research also used e-learning resources and journal.

\subsection{Literature Review}

\subsection{Training and Development of the Human Resource}

The world is changing at a very first rate, many things (services) have gone digital. Skill requirements have been changing so fast that individuals are hard pressed to keep up. There is no doubt that all individuals need some skills to be abreast with the fast moving world. It is evident that organizations are struggling to find people who bring in the skills and qualities needed. The implication therefore would be that the consecrated men and women are to have relevant modern skills in discharging their duties.

It is also observed that today's leaders and managers of corporations have to constantly address certain organizational needs due to heightened competition and increased demands for better quality and service D'Souza (2001). They cannot ignore the needs of employees for more involvements, more job satisfaction, learning opportunities and life training. That is why Okumbe (2007) emphasizes that all employees in essence all member of an organization regardless of their previous training, education and experience must be given further training and development. This is because the competence of workers never last forever. Beside, Armstrong (2016), state that different skills are required by a number of people, which have to be developed to meet new demands, thus they cannot be gained by relying on experience. Okumbe, (2007) enumerates importance of training as follows: is an investment in the human resource since it increases productivity due to acquisition of new skills; reduces problems which are associated with the supervision of employees because it enhances their ability to learn new work methods while helping them to adjust to changes in the content and context of their jobs; it greatly reduces dissatisfaction, enhances motivation and satisfaction at work; it increases stability of the organization since it creates a reservoir of qualified members who easily replace those who either transfer, retire or exit from the organization for various reasons; to a large extend it reduces work related accidents, this is because proper training in job skills and safety techniques enhances employee abilities to handle work-related equipment carefully. On-job-trainingmembers learn various aspects of their job while at the same time actually performing these tasks. Off the job training are those which members undergo outside their work environment

Armstrong (2016) alludes to the importance of training and development by stating that organizations need to invest in learning and development by providing appropriated learning opportunities and facilities. In so 
doing the organizations will maintain high productivity and hold sustained presence in the competitive world. The researcher's quick survey points that many institutes of consecrated life seem to provide their members with opportunities for training. However, the question that still lingers is whether the opportunities are appropriate and enable the institutes to achieve their goals and objectives.

\subsection{Selection and Placement of the Human Resource}

According to Okumbe (2007) selection is a very crucial process in the management of the human resource. In the light of business organizations, if the managers do not take into consideration the selection process the task of employee-job fit is not achieved then both the organization and the individual worker will suffer for obvious reasons. In institutes of consecrated life the same is true. The leadership while appointing members for mission or apostalate is to be keen to ensure that the individual members are not only able to fit into the assignment but also have tasks that they can take up after their training.

While developing this study the researcher continuously interacted with women and men religious on the study topic. During a given discussion one of the religious shared the following:

'I am happy that the leadership took me to school. I graduated two years ago with my master's degree. However, since then they have been telling me to wait for appointment. I have applied for a job and done interview when I am called to take up the job, I will do it gladly and only report back to the leadership that I have got a job. I know that the job is well paying and considering our financial struggle, the leadership will not object my move. This will also give me an upper hand to put forth my own demands. I am not the only one. The experience of our other three members is pathetic. They were taken for training but placed in areas not related to what they trained. Now they want to be taken back to school to get proper skills for the work. My other friend also told me that in their congregation even if you are taken for training it is assumed that with the training you can serve anywhere. Imagine a teacher being placed to work in a clinic!!!! When you question you are termed disobedient. These experiences are many and discouraging. However I want to say that some congregation do not do this. Case 1

Human resource development and allocation is part of planning exercise (Teklemariam \& Nam, 2011). Allocation would be similar to selection and placement. Therefore, just as the leadership of institutes of consecrated life plans to take its members for different training, they should also plan on where and how to place them after their studies. This is to be done appropriately in order to ensure that no member (s) are under or over exploited and misplaced or rather assigned tasks of which they do not have the required skills.

\subsection{Motivation of the Human Resource}

Although human beings have interacted with one another since the beginning of life, the art and science of trying to deal with human relationships in complex organizations is relatively new. Besides that understanding why people behave the way they do at work, in an institution or organization is a difficult job for the managers or leadership (Adhiambo, 2009). However, there is need to ensure that people's actions and behaviors propel the organization to the realizations of its goals and objectives. According to Kyalo (2017, pg. 31) 'motivation forms the starting point for seeking a particular vocation, thus is an important factor in religious life as it is in other vocations. No matter how foolish these motivations may appear, one should not be discouraged'.

It's good to note that members of institutes of consecrated life are not employees rather owners of the institute; however they can be likened to employees on a lighter note. This is because they are made of people from different backgrounds that come together to share a common vision and have a common goal to achieve. Therefore, if they are satisfied with the life; their apostolate, and other activities they shall be productive thus driving the institute towards sustainability. However, if they are dissatisfied with the life; apostolate and other related activities they shall be unproductive, the institute shall not grow and they may at a certain point leave the institute. This may be a setback on the growth and development of the institute. It is therefore important for the leadership to ensure that the members are satisfied with the activities of the institute. 
Further, the leadership is to empower individual members while putting in place effective mechanisms for the desired achievements, appreciation, create positive interpersonal relations, thereby creating positive and favorable attitudes (work motivators) towards the apostolate which indicate job satisfaction and vice versa. It is against this backdrop, therefore, that the researcher recognizes that it is critical for all members of the institutes of consecrated life to possess the requisite skills for service enrichment, control mechanisms of the task performance by other individual members and the experience for either developing or identifying appropriate further training programmes for the development of the members of the institute. The prime objective for this would be ensuring that the available human resources are maximally utilized to ensure sustainability of the institutes.

\subsection{Research Methodology}

The study adopted the mixed research paradigm. Johnson \& Christensen (2012) state that in mixed research; the researcher combines quantitative and qualitative research techniques, methods, or approaches to a single study. This allowed the researcher to examine more closely experiences encountered in the training and development the human resource in institutes of consecrated life. Besides that Oso \& Onen, (2009) opinion that a research design is either qualitative or quantitative. Therefore, the researcher narrowed down on descriptive survey design, which according to Lodico, Spaulding \& Voegtle (2010) uses quantitative approach. In a quantitative survey design, collection of data or information is mainly by administering questionnaires to a sample of individuals. Therefore, quantitative method was employed to capture the respondents' views on the study in the large target population.

\subsection{Samples}

According to Singh and Nath (2007), there is usually a trade of between the desirability of a large sample and the feasibility of a small one. Singh and Nath (2007) allude to that fact that sampling is indispensable technique and a research cannot be undertaken without it. A good sample therefore, is one that fully represents the population from which it is drawn (Johnson \& Christensen, 2012). Thus, there were approximately 207 total number of the men and women institutes of consecrated life in TUC and MIUC at the time of the study (TUC and MIUC Registry, 2017). Kothari (2004) alludes that a sample size of 10 $30 \%$ is acceptable. The researcher ensured that there were more than fifteen percent of the total populations of institutes on consecrated life to participate in the study. Therefore, the researcher wrote the names of the institutes in small pieces of paper. The papers were identically folded and put in a basket. The pieces of paper were thoroughly mixed. Using simple random sampling 34 folded papers were picked each at a time without replacement to maintain the probability. This enabled the researcher to get 14 female institutes and 20 male institutes, making a total of $16.2 \%$ of the approximate total number. This is in line with what Chandran (2004, pg. 94) pointed out that 'when the population is very large, the difference in probability of successive selections becomes negligibly small and does not violate the principle of randomness. Such a situation does not warrant samples being replaces in the population to keep the chance of selection constant from one section to the next'.

In addition, Singh and Nath (2007), indicate that samples of 30 or more are to be considered large and those with fewer than 30 small. Krejcie and Morgan (1970) recommend a sample size of 291 for a population of 1200. It was therefore representative enough to have a sample size of 304 ; individual members and their leadership included. This was done by giving all members of institutes of consecrated life an equal change of participating in the study. At MIUC where the population was less than 110 they were all included in the study. At TUC although all were given equal chances the target was 194. This was actualized during the distribution of questionnaires. The sample comprised of 270 individual members of the institutes of consecrated life and 34 members from the leadership. The researcher believed that individual members of the institutes formed a major sub - group for the study. This is because they are the human resource referred to in the study and the effect of training and development directly fell on them. Below are the findings with regard to the institutes of the respondents.

\subsection{Research Instrument Data Collection and Analysis}

According to Kothari (2004), while deciding about the method of data collection for the study, the researcher should keep in mind the type of data to be collected. A questionnaire is utilized when factual information and opinions are required with the use of attitude scale to gather data from a population sample 
(Best \& Kahn, 2005). According to Robson (2002), survey questions should be designed to enable the achievement of research objectives. The researcher developed two questionnaires one for the individual members and the other for those in leadership. The questionnaires had a short introduction that explained the purpose of the research (See appendices I \& II). The findings of the questionnaires were enriched by the interactive sessions captures as cases in the study.

The researcher engaged three research assistants in distribution of questionnaires. The researcher assistants were briefed on the purpose of the study, they were taken through the sampling procedures, thereafter sent to the sampled institutes. They had one month to bring back the filled questionnaires. It was observed that some respondents were quick and gave back the questionnaire within a week; others took two to three weeks respectively while another group did not return the questionnaire. The research assistant brought the questionnaires on the agreed data and reported on the challenges that they faced during the data collection process.

The researcher organized the data into quantitative and qualitative data. The Statistical Package for Social Science (SPSS) version 21.0 was used in quantitative analysis. Qualitative data obtained from open - ended questions from the questionnaires were analyzed as follows: The researcher condense the data by editing, paraphrasing and summarizing in order to become meaningful. Data that did not fall under the established themes was examined critically and emerging unexpected themes were created. The findings have been interpreted and presented either verbatim or as narratives.

\subsection{Findings And Results}

\subsection{Analysis of the Questionnaire}

As earlier mentioned, two questionnaires were developed for data collection. The findings of the two questionnaires have been reported concurrently. The feedback of the individual members and that of the leadership is reported simultaneously. Descriptive and inferential statistics were used in data was analysis. Quantitative data have been presented in figures, tables and in numerical calculations. The hypotheses were tested using ANOVA; One-way ANOVA and One Sample T-Test. The test static value or the critical value was 0.05 . This means the hypothesis was rejected if the $\mathrm{P}$ value is less than $0.05(\mathrm{P}<0.05)$. Qualitative data enriched the findings.

\subsubsection{Questionnaire Return rate}

A total of 270 individual members were sampled and 34 leaders from regional, provincial and general leadership. Although a sum of 304 questionnaires were distributed to the sampled respondents, 242 (89.6\%) individual members' questionnaires were returned and $20(58.8 \%)$ questionnaires for the leaders of institute of religious life were returned. This was considered acceptable hence the researcher proceeded with data analysis.

Figure 1.0: Category of the Individual Member's Institute of Religious Life 


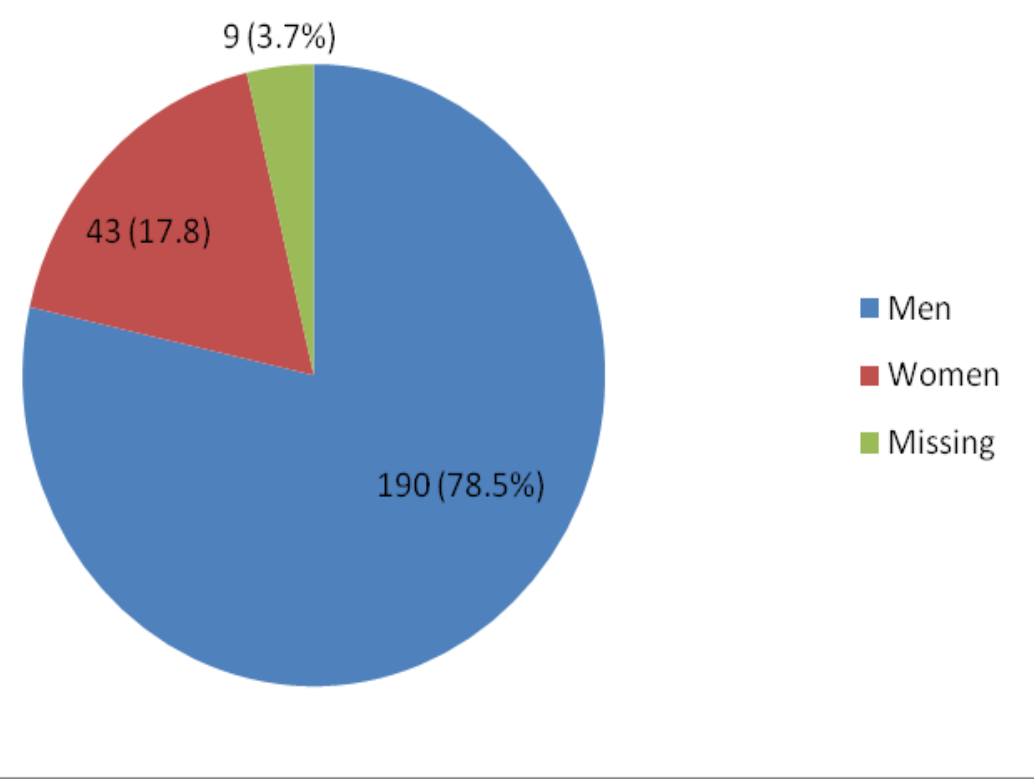

From the data collected majority 190 (78.5\%) respondents belonged to men religious institutes (male), 43 (17.8\%) from women religious institutes (female) while $9(3.7 \%)$ did not indicate which institute they belonged to. This may be associated with the fact that TUC and MIUC as learning institutions are dominated by male religious based on their historical development background outlined in section 1.7. In addition among the data collection assistants male religious were more, this could have also affected the outcome. It's interesting to note that, there were an equal number of men $10(50 \%)$ and women $10(50 \%)$ members of the various leadership teams who took part in the study.

\subsection{Training and Development}

According to Okumbe (2001), one of the objectives of training and development in organizations is it creates a reservoir of qualified personnel who easily replace those who exit from the organizations for various reasons. The researcher listed a number of questions on this section to be able to establish how training and development is done in institutes of consecrated life.

Figure 2.0: Training Opportunities for Members

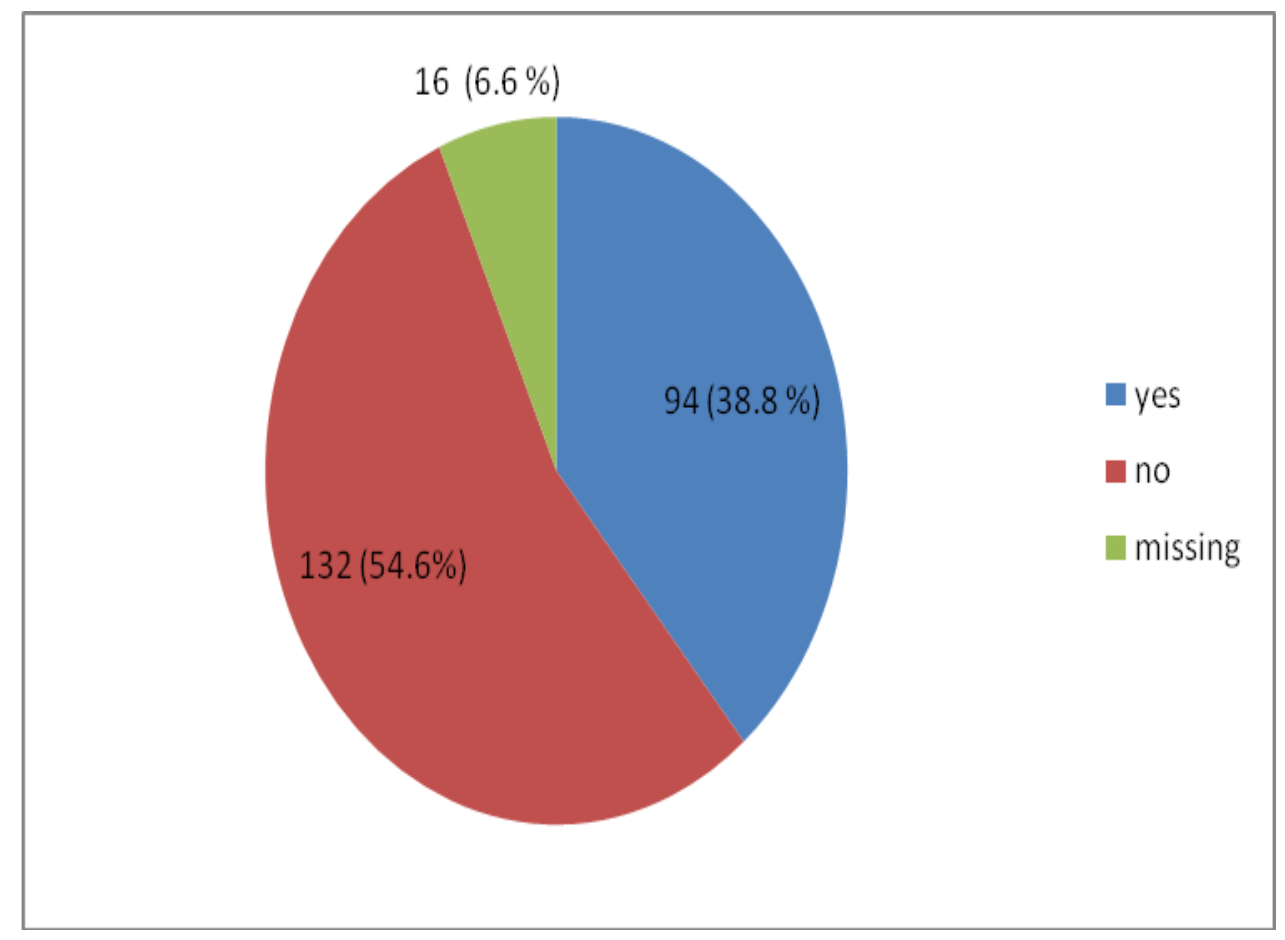


The findings in Figure 2.0 above show that 132 (54.6\%) of the respondents said no, 94 (38.8\%) said yes while $16(6.6 \%)$ did not respond to the question as to whether the leadership gives equal training and development opportunities to members. Just as Okumbe (2001), states that no single employee is a perfect fit at the time of hiring; it is vital that training must take place. Similarly in institutes of consecrated life no single member is a perfect fit considering that they join the institute with various level of education and they are also appointed for apostolate with different background experience.

\section{Figure 3.0: Training of Members in the Light of their Talents}

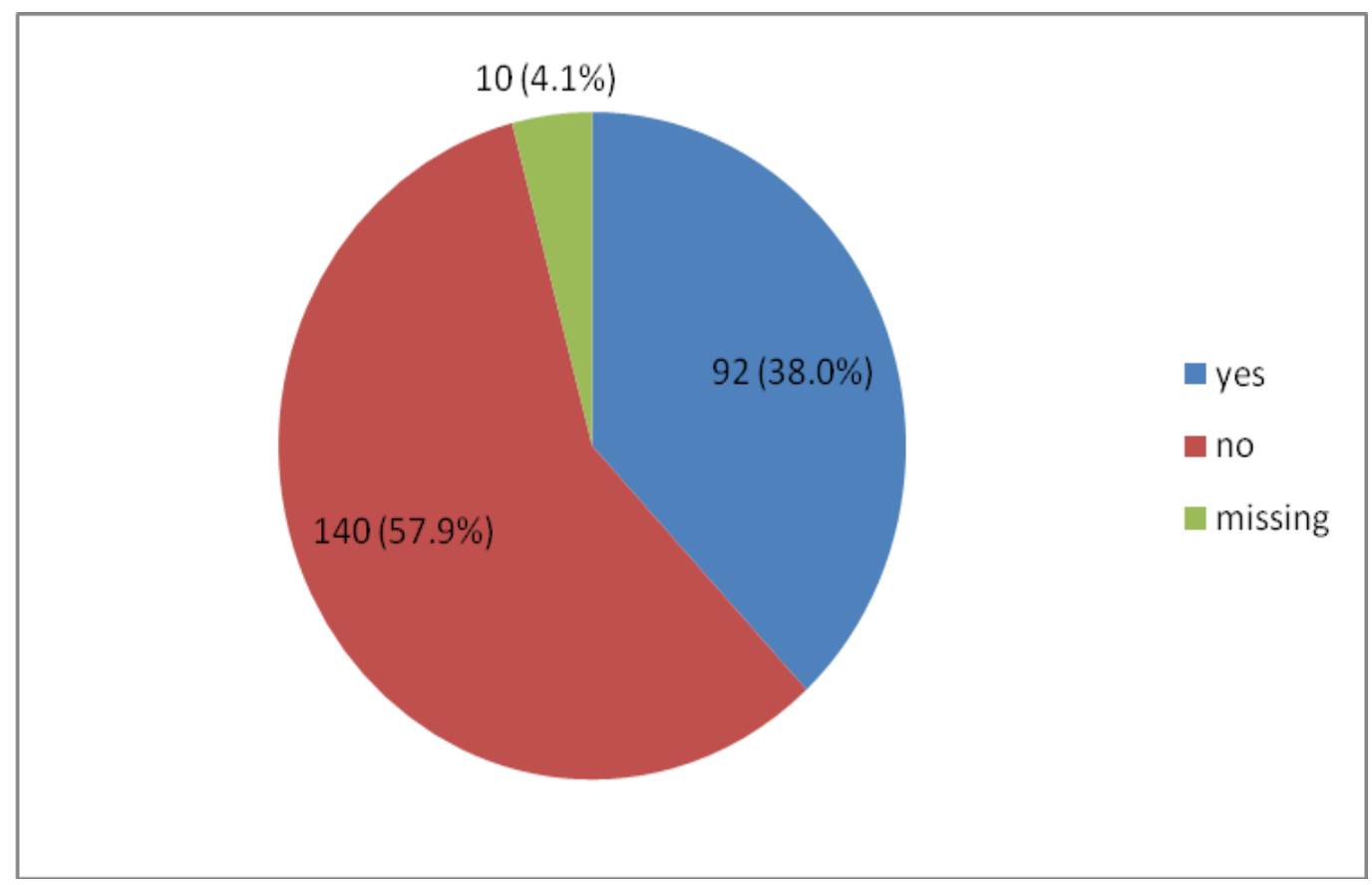

Figure 3.0 above shows that $140(57.9 \%)$ of the respondents stated that the leadership does not train members according to their talents, $92(38.0 \%)$ indicated that members are trained and developed according to their talents while $10(4.1 \%)$ did not answer the question. In giving explanation to their responses 102 $(42.1 \%)$ said that the gifted and talented are given priority for training for efficiency, in this case the respondent might have been referring to the persons that are talented. Another group of $64(26.4 \%)$ expressed that members are taken for granted as programs are fixed, they are compulsory regardless of one's gifts and talents and the leadership takes individuals for the training 'they' think a person can do without consultation. Of greater interest was the revelation by $56(23.1 \%)$ that training is done on those appointed by the superior and for the leadership interests, priority and choice. reading the statements challenges one to think critically and ask questions that might be of serious concerns such as does it mean that if one is not chosen by the superiors she or he cannot be taken for training? is there a criteria that the superior use to appoint those to be trained for leadership interests? what if none of the trained becomes a leader? $20(8.3 \%)$ did not simply say anything.

All the superiors agreed that they do train members according to their gifts and talents. In unison they stated that they evaluate on individual's talents and take into consideration the interests of members in order to tap talent. This is however not the bigger picture reflected by the individual members. It is important for all members of institutes of consecrated life to realize that learning of new skills is not done through trial and error or simply by watching others. Training of is extremely important because this has to do with development and acquisition of new skills necessary for service delivery.

While acknowledging that talented people possess special gifts, abilities and aptitude which enable them to perform their tasks effectively (Amstrong, 2009), it is necessity for institutes of consecrated life to strengthen their talent pool through training and development in order to increase productivity and remain relevant. Members are not only supposed to be trained in line with the apostolate of the institute but in conjunction with individual talents. It's clear therefore, that if institutes of consecrated life have to keep to 
their vision and maintain their presence in the ever changing world there is need of the leadership to take note of how they train their members. This shall not only ensure affectivity and efficiency in service delivery but also blend the individual Charism with the congregational Charism thus ensuring sustainability of the institute and low turn-over of members.

\subsubsection{Importance of Training Members}

Okumbe (2001) asserts that training, improves morale and motivation, it enhances ones abilities to learn new work method and to adjust to changes in both the content and context of the task. It is therefore of high value to train members in any institute of consecrated life. Many benefits come along with this attributes as revealed in the findings that training promotes productivity, efficiency, relevance and growth of the congregation; it promotes a sense of responsibility, sense of belonging and good communication among members; and it enhances leadership skills, knowledge, understanding a broad perspective of the world.

These were supported by the feedback from the superiors who asserted that training forms the basis of good leadership. The superiors believed that training impacts knowledge and helps bring about the efficient and competent members for future leadership. It helps members acquire relevant skills and knowledge, enables members to perform responsibilities with informed knowledge and thus ensuring efficiency and it helps in preparation of members for various services and motivates them in their work. If this is the case then why are members not given equal training opportunities? Why they are not trained in the light of their talents? That is why Okumbe (2001) states that training and development are a must. So it is left for the leadership of institutes of consecrated life to come up with the suitable method of ensuring that their members get the relevant training and needed development. As they think about this, it's important for them to also realize that they need to plan for training programmes; otherwise there shall be high costs incurred not only because their members will take too long to learn the required skills but also because of the possibility that they will not learn the best methods necessary for their apostolate.

Table 1.0: Individual Member Training

\begin{tabular}{|c|c|c|c|c|c|c|}
\hline & \multicolumn{6}{|c|}{ Frequency (percentage \%) } \\
\hline Statement & $\begin{array}{l}\text { Strongly } \\
\text { Agree }\end{array}$ & Agree & Disagree & $\begin{array}{l}\text { Strongly } \\
\text { Disagree }\end{array}$ & $\begin{array}{l}\text { Missing } \\
\text { values }\end{array}$ & Total \\
\hline $\begin{array}{l}\text { My congregation has training policies } \\
\text { for the members. }\end{array}$ & $\begin{array}{l}65 \\
(26.9)\end{array}$ & $\begin{array}{l}100 \\
(41.3)\end{array}$ & $54(22.3)$ & $23(9.5)$ & - & $242(100)$ \\
\hline $\begin{array}{l}\text { All members have the opportunity for } \\
\text { spiritual training and development. }\end{array}$ & $\begin{array}{l}81 \\
(33.5)\end{array}$ & $\begin{array}{l}101(4 \\
1.7)\end{array}$ & $\begin{array}{l}44 \\
(18.2)\end{array}$ & $16(6.6)$ & - & $242(100)$ \\
\hline $\begin{array}{l}\text { Professional training of members is a } \\
\text { priority for the leadership. }\end{array}$ & $17(7.0)$ & $\begin{array}{l}77 \\
(31.8)\end{array}$ & $\begin{array}{l}98 \\
(40.5)\end{array}$ & $\begin{array}{l}50 \\
(20.7)\end{array}$ & - & $242(100)$ \\
\hline $\begin{array}{l}\text { All members have equal opportunity } \\
\text { for professional training and } \\
\text { development. }\end{array}$ & $\begin{array}{l}30 \\
(12.4)\end{array}$ & $\begin{array}{l}30 \\
(12.4)\end{array}$ & $\begin{array}{l}116 \\
(47.9)\end{array}$ & $\begin{array}{l}62 \\
(25.6)\end{array}$ & $4(1.7)$ & $242(100)$ \\
\hline $\begin{array}{l}\text { The leadership ensures that all } \\
\text { professionally trained members are } \\
\text { engaged in sustainable apostolates to } \\
\text { support the community and } \\
\text { congregation. }\end{array}$ & $\begin{array}{l}30 \\
(12.4)\end{array}$ & $\begin{array}{l}83 \\
(34.3)\end{array}$ & $\begin{array}{l}90 \\
(37.2)\end{array}$ & $\begin{array}{l}39 \\
(16.1)\end{array}$ & - & $242(100)$ \\
\hline $\begin{array}{l}\text { Professionally trained members earn } \\
\text { sufficient to sustain the community } \\
\text { and the congregation }\end{array}$ & $24(9.9)$ & $\begin{array}{l}82 \\
(33.9)\end{array}$ & $\begin{array}{l}91 \\
(37.6)\end{array}$ & $\begin{array}{l}45 \\
(18.6)\end{array}$ & - & $242(100)$ \\
\hline $\begin{array}{l}\text { Majority of professionally trained } \\
\text { members leave the congregation as } \\
\text { soon as they complete their training. }\end{array}$ & $15(6.2)$ & $\begin{array}{l}36 \\
(14.9)\end{array}$ & $\begin{array}{l}98 \\
(40.5)\end{array}$ & $\begin{array}{l}85 \\
(35.1)\end{array}$ & $8(3.3)$ & $242(100)$ \\
\hline
\end{tabular}

It was important to explore further into training, therefore a number of questions were asked. The findings on table 6.0 above reveal the following: most of the respondents $165(68.2 \%)$ agreed that their congregations 
have training policies for the members while 77 (31.8\%) disagreed that their congregations did not have policies. This number cannot be ignored considering that the respondents came from different institutes therefore it may be true that some institutes do not have the policies. On the other hand they may be not aware of the presence of the policies. It is therefore important the leadership of the institutes of consecrated life to ensure that the institute has training policies and members are made aware.

The following hypothesis was tested.

\section{$\mathrm{Ho}_{1}$ : There is no significant relationship between category of the institute and availability training policies of the human resource in institutes of consecrated life.}

According to the analysis $\mathrm{P}<0.05$ (See Appendix III), therefore the null hypothesis is rejected. Thus availability of training policies is dependent on the category of the institutes. This further means that there are institutes that have training policies for their members and others do not have.

When asked whether all members have equal opportunities for spiritual training and development, majority $182(75.2 \%)$ agreed while $60(24.8 \%)$ disagreed. Spiritual training and development may be approached in different phases of an individual's life. For instance during formation all men and women religious are exposed to various trainings that are geared towards this. After the years of formation, different institutes have different approaches while some have made it mandatory that before taking up any task their members is to undergo some spiritual training others do not. This may have contributed to the above findings above, nevertheless the leadership of various institutes of consecrated life is to realize that spiritual training and development is the pillar of their apostolic ministry. Underlining that to be a woman or man religious is a call, the need for continuous spiritual training and development is important because this keeps the members grounded, strong and firm in faith in the present dynamic society.

Regarding professional training of members being a priority for the leadership, 94 (38.8\%) agreed while 148 $(61.2 \%)$ disagreed. If this is the case, how then are the institutes going to sustain themselves. In Kenya at the moment working in all sectors one needs academic papers. As shared by a member of the leadership of a certain institute "currently the Bishops are asking us to submit academic papers of our members for any apostolate. Recently a diocese wanted to employ a social worker in one of the parish; we lost the opportunity to another congregation because the minimum qualification was a master's degree. Previously we lost an opportunity in a diocesan hospital because they needed a bachelor's degree holder to be a nurse. We also faced a challenge while we wanted to transfer one of our members who had served as a catechist for eight years in some parish in a different diocese. The Bishop challenged us to bring a diploma holder in catechesis we did not have, a non-consecrated person was taken.

We are not the only congregation facing these, another colleague from another institute shared with me that they have not only lost opportunities in three dioceses they are working but also in catholic sponsored schools near their communities due to lack of qualified personnel for the posts advertised. However these are not the only challenges, we are also faced with the fact that we work in dioceses and the remunerations that we receive is more of a stipend rather than a salary. This is because our services as men and women religious in dioceses where we exercise and practice our spirituality are seen more as pastoral work. With this it's very difficult for us as leaders because our life as institutes of consecrated life is part and parcel of the Church and we cannot choose to work completely outside". Case 2

Considering that religious life was born and developed as ecclesial life throughout the centuries as expressed by Mattan (1994) that God calls a person to a specific way of life in the Catholic Church, institutes on consecrated life express their Charism and spirituality in the Church, thus they work in most of the Church related apostolate. Therefore the above sharing confirms the need for the leadership of institutes of consecrated life to urgently prioritize professional training of their members. Further interrogation on this was explored by asking if all members have equal opportunity for professional training and development 60 (24.8\%) agreed while a vast majority 178 (73.6\%) disagreed, 4 (1.7\%) did not answer the question. This also confirms the challenge shared below: 
"I am pursuing this course because my superiors told me to. Ideally I have no passion for teaching; I am not gifted in any way to be a teacher. I do not know what I will do during teaching practice. Besides that my performance is poor. I have tried explaining to them in vein. Recently I received a warning letter that I am disobedient because of my persistent effort to make them see that this course is not my cup of tea. What frustrates most is that majority of us in the institutes have been sent to pursue courses without consultation. In fact some of the members in the field cannot deliver. Others are struggling with the responsibilities given to them, simply because the word of the superiors is first and last. Besides some of our members desire to pursue what I am doing but they have not been given the opportunity'. Case 3

Thus training and equal training opportunities in various fields of members to the highest possible level is essential so that the institutes have a variety of a pool from which members are drawn when an opportunity arise.

On whether the leadership ensures that all professionally trained members are engaged in sustainable apostolates to support the community and congregation 106 (43.8\%) agreed while 136 (56.2\%) disagreed. Although there is a thin line between those who agreed and those who disagreed it is clear that sustainability is an issue. This is because to ensure sustainability members have to be professionally trained to get good jobs that are well paying so that what they earn goes into their livelihood and all other related things. Since the leadership of institutes of consecrated life are aware of what is happening it is their responsibility to ensure that the institutes gets the necessary resources to achieve its goals and objectives while keep their Charism and spirituality alive active. This has to be done while putting into mind that donor funding support which the institutes of consecrated life used to enjoy is no longer available.

Ivancevich, Matterson and Konopaske (2011) assert that key to an organization's success is the institution's human resource. This is because organizations can effectively achieve their needs through the human resources who work hard, think creatively and perform excellently the task assigned to them. Like any other organization members of institutes of consecrated life are the key resources'. The study sought to establish whether professionally trained members earn sufficient to sustain the community and the congregation 106 (43.8\%) agreed while $136(56.2 \%)$ disagreed. This may be associated with what was revealed in Case 2 that the services offered by the men and women religious are remunerated low and possibly majority of the respondents came from institutes whose apostolates are largely found within dioceses. This is still a challenge for the leadership of institutes of consecrated life to ensure that their trained members earn commensurate to their qualifications just like in other sectors. This is because sustainability is key to the existence of an institute and the wellbeing of its members.

Most interesting in this section was the revelation of a vast majority 183 (75.6\%) who confirmed that majority professionally trained members do not leave the congregation as soon as they complete their training, although $51(21.1 \%)$ indicated that they leave while 8 (3.3\%) did not respond to the question. This revelation should be an encouragement to the leadership of institutes of consecrated life, especially those who do have not prioritized professional training of their members.

\subsubsection{Development of Members}

Amstrong (2009) observes that the concern of development is to ensure growth of a person's ability and potential through provision of learning experiences or through self-directed learning. This involves learning activities that prepare people to exercise wider or increased responsibilities. Something that is key to institutes of consecrated life because the seldom have the opportunity to decide of what type of apostolate they take up.

Table 2.0: Individual Members Development

\begin{tabular}{|l|l|l|l|l|l|l|}
\hline & \multicolumn{7}{|c|}{ Frequency (percentage \%) } \\
\hline Statement & $\begin{array}{l}\text { Strongly } \\
\text { Agree }\end{array}$ & Agree & Disagree & $\begin{array}{l}\text { Strongly } \\
\text { Disagree }\end{array}$ & $\begin{array}{l}\text { Missing } \\
\text { values }\end{array}$ & Total \\
\hline $\begin{array}{l}\text { The leadership has designed } \\
\text { orientation programmes for all } \\
\text { members while taking up tasks within } \\
\text { the congregational projects. }\end{array}$ & $\begin{array}{l}40 \\
(16.5)\end{array}$ & $\begin{array}{l}100 \\
(41.3)\end{array}$ & $\begin{array}{l}79 \\
(32.6)\end{array}$ & $14(5.9)$ & $9(3.7)$ & $242(100)$ \\
\hline \hline
\end{tabular}




\begin{tabular}{|l|l|l|l|l|l|l|}
\hline $\begin{array}{l}\text { When appointing members for } \\
\text { apostolates the leadership provides } \\
\text { them with details of the tasks } \\
\text { descriptions and the overall } \\
\text { expectations of work related } \\
\text { activities. }\end{array}$ & $\begin{array}{l}53 \\
(21.9)\end{array}$ & $\begin{array}{l}98 \\
(40.5)\end{array}$ & $\begin{array}{l}70 \\
(28.9)\end{array}$ & $11(4.5)$ & $10(4.1)$ & $242(100)$ \\
\hline $\begin{array}{l}\text { The leadership gives members } \\
\text { opportunities for on- the-job training. }\end{array}$ & $\begin{array}{l}37 \\
(15.3)\end{array}$ & $\begin{array}{l}120 \\
(49.6)\end{array}$ & $\begin{array}{l}62 \\
(25.6)\end{array}$ & $14(5.9)$ & $9(3.7)$ & $242(100)$ \\
\hline $\begin{array}{l}\text { The leadership gives members } \\
\text { opportunities for off - the- job } \\
\text { training. }\end{array}$ & $\begin{array}{l}105 \\
(43.4)\end{array}$ & $\begin{array}{l}79 \\
(32.6)\end{array}$ & $15(6.2)$ & $19(7.9)$ & $242(100)$ \\
\hline $\begin{array}{l}\text { The leadership encourages members } \\
\text { to learn from each other as they work } \\
\text { together. }\end{array}$ & $\begin{array}{l}73 \\
(30.2)\end{array}$ & $\begin{array}{l}129 \\
(53.3)\end{array}$ & $24(9.9)$ & $8(3.3)$ & $8(3.3)$ & $242(100)$ \\
\hline
\end{tabular}

Since development's primary concern is knowledge acquisition and the enhancement of executives' conceptual, diagnostic and human abilities, Teklemariam (2009) opinions that this may occur in various forms. The researcher therefore, posed the following statements: The leadership has designed orientation programmes for all members while taking up tasks within the congregational projects; when appointing members for apostolates the leadership provides them with details of the tasks descriptions and the overall expectations of work related activities; the leadership gives members opportunities for on- the-job training; the leadership gives members opportunities for off - the- job training; the leadership encourages members to learn from each other as they work together. On all statements the findings reveal a similar trend that majority of the respondents agreed while a few disagreed. The few that are disagreeing cannot be ignored.

It is important for the leadership of the institutes of consecrated life to know that development of members is recognition of the fact that all people may improve their abilities and become more efficiency and effective in whatever they are doing. Thus, continuous development is necessary.

\subsection{Selection and Placement}

Selection is a lengthy and complex process as it involves a series of steps before making the final decision on choosing the most suitable candidate for a position in the organization. Placement is ensuring that the selected individual has been assigned the relevant task. A number of questions were asked in this section.

\subsubsection{How does the Leadership allot work?}

The question was very essential in the research as this would lay the ground on how the leadership works and helps its members to fulfill the needs of the congregation at the same time respecting its members. From the analysis, the following outcome was uncovered: This is done according to the availability of a postulate, dialogue with the individual to be engaged and then appointment 29 (12.0\%), with respect to talents, professionalism, personality, interests, ability and the needs of the community 107 (44.2\%), on relational basis and favoritism 8 (3.3\%). A small group 36 (14.9\%) of respondents did not answer the question.

While agreeing that work allotment is a very important process, the superiors indicated that each institute of consecrated life has put in place unique ways of doing this. It was observed that majority $16(80 \%)$ quipped that work allotment entirely depends on the individual needs of the institute of consecrated life, $3(15 \%)$ indicated that is relies on the capability and talents of members while $1(5 \%)$ said it is effected through appointments by superior irrespective of one's capability. This implies that one's an individual has been appointed to take up a task he or she had to do so.

\subsubsection{Commissioning of Members}

The figure below captures the findings in relation to commission of members.

Figure 4.0: Commissioning of Members 


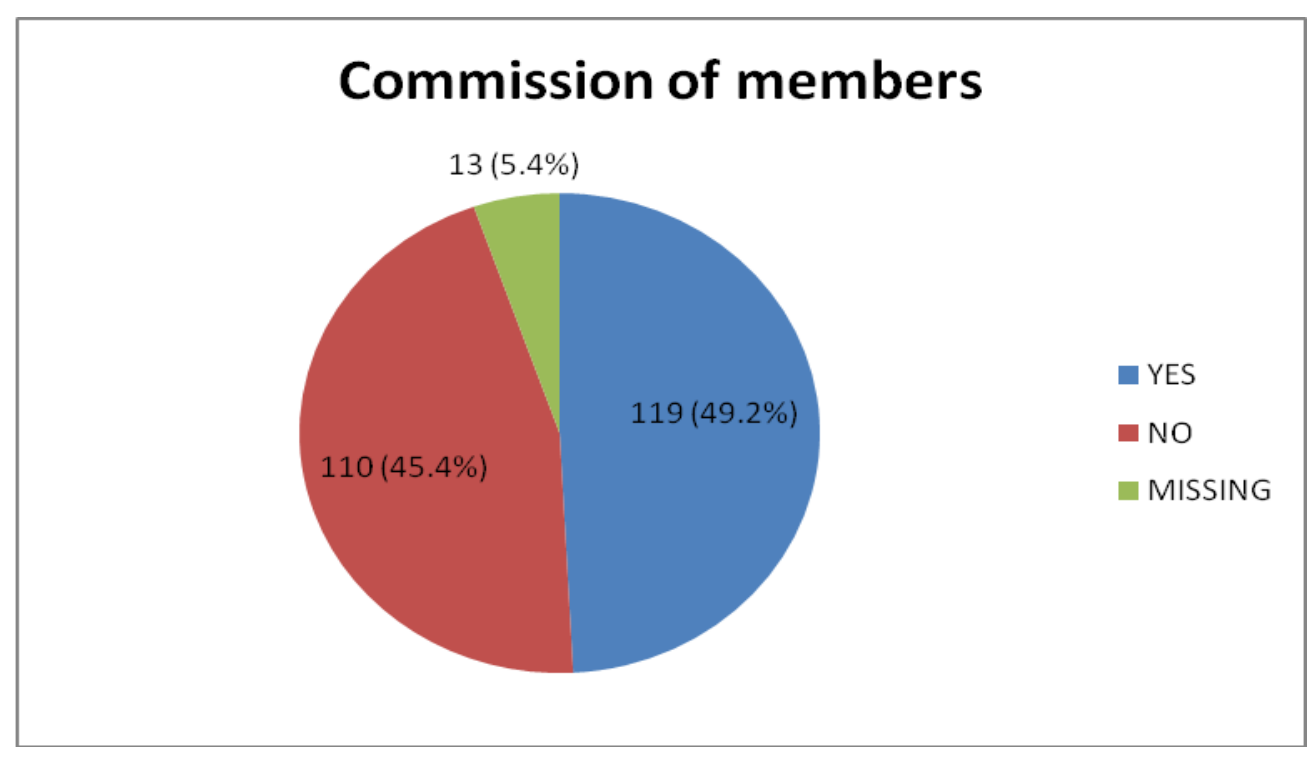

Although it is evident the leadership commissions members for apostolate depending on the individual's ability and talent 119 (49.2\%), it is also clear that 110 (45.4\%) expressed the leadership does not and 13 (5.4\%) did not respond to the question. Those who disagreed share similar sentiments with the findings from the leaders in 4.7.1 paragraph 2. These findings reveal that there are cases where the leadership considers the individual's ability and talents while in some cases they do not.

The variables the leadership commissions' members depending on the individual's ability and talent with the category of the institute, were used to test the following null hypothesis.

$H_{02}$ : There is no significant relationship between category of the institute and commissioning of members by the leadership in the light of individual's ability and talent.

The findings indicate that $\mathrm{P}<0.05$ (See Appendix V) therefore, the hypothesis is rejected.

\subsubsection{Tapping the Human Potential for Sustainable Development of the Congregation.}

The human potential in every organization plays a major role in development. By way of tapping this attribute in the congregation, there is a guarantee of continued development in the congregation.

The Figure 5.0 below shows the findings from the individual members' point of view. There is a very small margin between those who said yes 125 (51.7\%) and those who said no 117 (48.3\%). When asked to explain their response, the following answers were given. Those who said yes indicated that this is done through training for mission and exposure to improve the individual skills and that each member is given opportunity to participate in decision making geared towards the development of the congregation. On the other hand those who said no indicated that the leadership is not aggressive or in a hurry to work towards tapping members talents for congregational sustainable development, they only focus on community needs. Besides that no training and appointment of members is based on their talents and abilities.

\section{Figure 5.0: Tapping Human Potential}




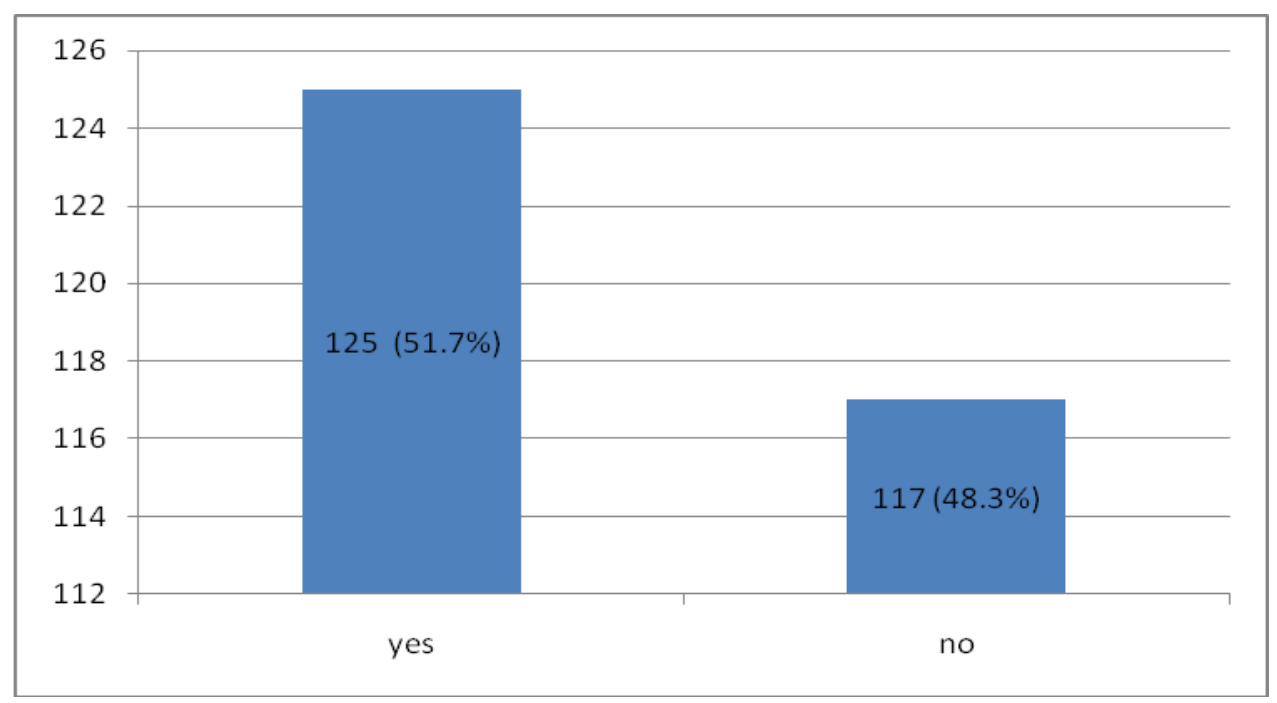

The question was posed to the leaders; it aimed at a leader's individual opinion on whether he/she has tapped human potential to promote development in the congregation. The summary of the varied responses are as follows: No, a lot of gap still missing such as lack of personnel and finance $10(50.0 \%)$, Yes, through dialogue and training $5(25 \%)$ and appointing and allocating work based on gifts and talents $5(25 \%)$.

\subsubsection{Appointment and Placement of members}

The study further sought to establish whether the appointments and commissioning done by the leadership focuses on the sustainable development of the institute of consecrated life. The findings from the individual members reveal that majority $186(76.9 \%)$ of the respondents said yes while $56(23.1 \%)$ of the respondents stated no. In their explanations the respondents mentioned that, this was done basing on the apostolic need of the institutes. Some further explained that they what they get is not sufficient to cater for their needs in the community, in most cases the leadership has to send more finances to sustain their daily living.

The leaders on the other hand held similar opinion that that the leadership does commissioning and appointment focused on the sustainable development of the institute. However, they face a challenge of ensuring that the Charism of the institute continues to find meaning in the present world by ensuring they are actively involved in charity apostolates as well as apostolates that bring in good income for the institute. Nevertheless a good percentage $(80 \%)$ of superiors agreed that although balancing the two remains a big challenge they try to identify interest and talents of members at times before appointing and commissioning them. It was interesting to get responses such as this enable the institute of consecrated life to be self-reliant; avoid too much interference; appointment is done through follow-ups and evaluation of laid down projects. These responses were found to be parallel to the question that was asked

\subsection{Motivation}

Motivation is essential and there is need to encourage it in institutes of consecrated life.

Figure 6.0: Members Motivation by the Leadership

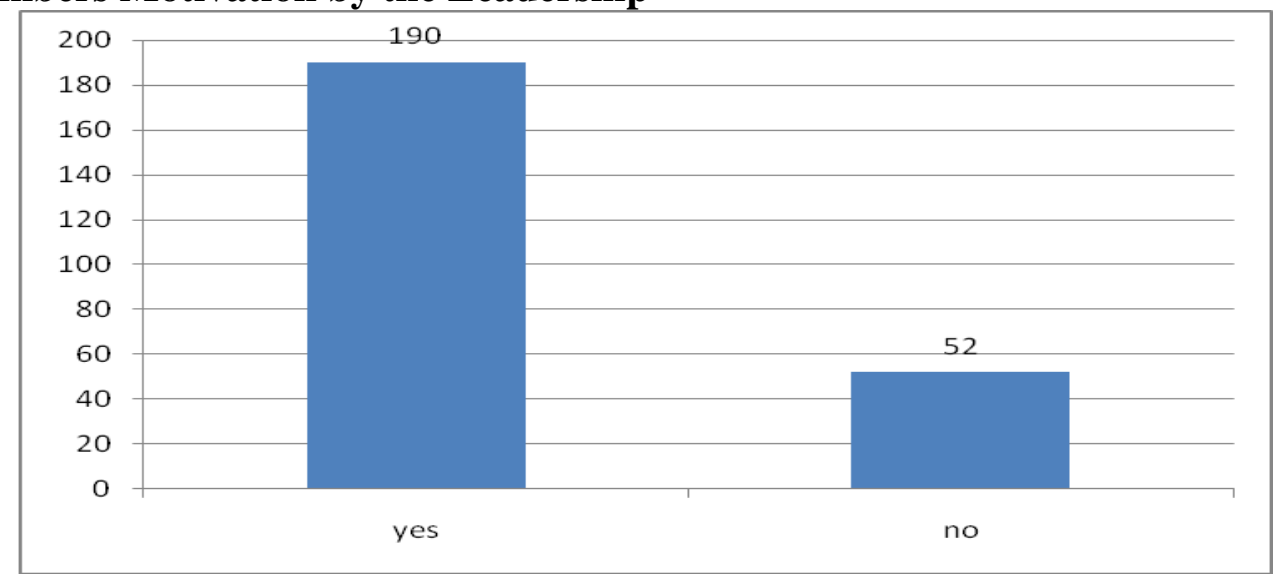


The findings of the Figure 6.0 above reveal that majority 190 (78.5\%) of the respondents gave a positive feedback that they are motivated by their leadership, a small $52(21.5 \%)$ indicated that they are not motivated by their leadership.

Using One-way ANOVA the variables does the leadership motivate members in their apostolate; the leadership often visits members in their apostolate to encourage them; the leadership supports individual initiative towards realization of congregational goals and category of the institute the following null hypothesis was tested.

\section{$H_{03}:$ There is no significant relationship between category of the institute and practical motivational approaches used by the leadership in institutes of consecrated life.}

\section{The findings indicate that $P<0.05$ (See Appendix $V$ ) therefore the null hypothesis is rejected.}

The qualitative findings support the above conclusion. This is because the findings indicate that the leadership tries to motivate the members in their daily work and continued participation in the apostolate. These are the motivational approaches highlighted: member's involvement in planning, meetings and frequent leadership visitations of members (29.3\%), training according to ones interests and talents (32.6\%), appreciation through promotion, reward, encouragement and retreats $(21.5 \%)$. However a few mentioned there were no specific motivational techniques $(16.5 \%)$.

Aside from the motivational technique, the researcher also wanted to know whether over time the individuals have been motivated by these techniques in the apostolate in the congregation. The following individual responses were gathered: that being appreciated, supported and encouraged for good work and when things are hard 50 (20.7\%); ensuring suitable work conditions, availability of resources, growth and development of an individual 25 (10.3\%); cooperation, consultation and frequent invitations from the leaders 59 (24.4\%); being given opportunities to able to pursue one's talents, gifts and potentiality 24 (9.9\%); $36(14.9 \%)$ expressed that they were not motivated while $48(19.8 \%)$ did not respond to the question. The superiors on the other hand shared that they motivate members by providing needs and support in their apostolates and encouraging collaboration and cooperation for good work using the mission and vision of the congregation.

The findings further reveal that as a way of motivating members in there apostolate $162(66.9 \%)$ of the respondents agreed and strongly agreed that the leadership visits members in their places of apostolates to encourage them, $80(33.1 \%)$ disagreed with the statement. It was also interesting to note that $76(31.4 \%)$ of the respondents agreed that the leadership only visits members in their places of apostolate to solve conflicts while $166(68.6 \%)$ disagreed with the statement. Another interesting scenario was observed when 56 (23.1\%) agreed that the leadership does not visit members in their places of apostolate while a majority 186 (76.9\%) disagreed with the statement. These are striking revelations in the study. It is important to emphasize that motivation of the human resource is paramount for productivity purposed. Therefore, the leadership of institutes of consecrated life ought to take serious note of motivation of its members.

\subsection{Analysis of the Interactive Sessions}

As earlier mentioned the researched engaged the target group in various interactive sessions from the beginning of the study to the end. This is one $f$ the reasons why the research did not carry out interviews. The interactive sessions enriched the study in that individual member sharing were captured in various sections of the study as presented below:

1. Case 1 (Section 2.1,pg. 7-8) indicates that there is a lapse in the management skill of planning in the light of training and development of the human resource with specific focus on selection and placement. While projecting the human resource needs and the professional demands of the apostolate in institutes of consecrated life. It is paramount that those in leadership put in place strategies to ensure that their members are appointed to places of service in line with the skills that they have trained for.

2. Case 2 (Section 4.2.1, pg. 21) reveals lack of diversified and competitive professional training opportunities in some institutes of consecrated life. That is why the institutes are missing 
opportunities. It is important for the leadership of consecrated life to ensure that the various apostolic works have sufficient professionally strained human resource base where they can always get someone to take up upcoming opportunities.

3. Case 3 (Section 4.2.1, pg. 22) directly challenges the vow of obedience in which consecrated men and women are expected to listen, take instructions and follow from their leadership without questioning. Although every person needs continuous training and development to improve their skill. It is important that institutes of consecrated life realize that people work best in what they have passion for.

\subsection{Summary, Recommendations and Conclusions \\ 5.1 Introduction}

In this chapter, the researcher presents the summary of the findings, conclusions drawn from the findings, recommendations and suggestions for further research.

\subsection{Summary of the Findings}

1. There is relationship between category of the institute and availability of training policies of the human resource in institutes of consecrated life. The findings point to the fact that some institutes have training policies while others do not have. As such training and development of members does not follow a particular standard rather it depends on the leadership in place, availability and the needs of the congregation (Sections 4.2.1 pg. 18 -22). The respondents unanimously agreed that training of members is important.

2. There is relationship between category of the institute and commissioning of members by the leadership in the light of the individual's ability and talent. Although the concept of selection, placement or commission or appointment for apostolate is taken into consideration by the leadership of institutes of consecrate life. A lot still has to be done to improve the operations and ensure sustainable development, growth and existence of the institutes of consecrated life (Section 4.3.2, pg. $26-27)$.

3. There is relationship between category of the institute and practical motivational approaches used by the leadership in institutes of consecrated life. The findings show that members are motivated in the following ways involvement in planning, meetings, frequent visitations, training according to interests and talents, appreciation through promotion, reward, encouragement and retreats among others (Section 4.4, pg. 29-30).

\subsection{Recommendations}

1. Training and development is one of the human resource management functions that leaders cannot ignore. This is because these help to foster and maintain members skills that enable them work towards achieveing organizational goals and objectives. Beside that Teklemariam (2009) states that strategic approach to human resource management recognizes that employees, in this case members of institutes of consecrated life as assets, they make things happen and give organization a competitive advantage. These being the case members are to be given equal training opportunities to create a sense of personal growth and to increase their value contribution to the institute.

2. Although institutes of consecrated life are called to service. The research, challenges the leadership of the institutes that appointment and commissioning of members without consultation and taking into consideration individual's talents and ability in the light of the human resource management in most cases leads to poor service delivery, de-motivation on the part of the individual thus affecting the entire workforce. The leadership must now and then realize that their individual members are the institute's key resources, whatever they do; they must be actively involved so that they are able to give quality output. It is also important for the leadership of all institutes of consecrated life to know that people work better, give highly quality productive results when they handle what they are good at. Besides that handling what one knows propels an individual to want to learn new things from that area and other areas to enrich their ability and talents.

3. As Kyalo (2017) opinions, motivation to religious life can change within the span of a year or even less, nevertheless member's motivation for joining religious life must be kept at the fore throughout. The leadership must ensure on their part that whatever they do is not de-motivation to the members. 
While members on the other hand must take responsibility of their life and challenge practices that do not motivate them.

\subsection{Further Study and Research}

The findings have a bearing on the male institutes of consecrated life. This is believed to have affected the results by pointing out what largely happens in the male institutes of consecrated life because they were more male than female (See Figure 1.0, pg. 60). Therefore the researcher recommends that a comparative study on leadership styles and motivational approaches to be carried out between diocesan and pontifical institutes of consecrated life.

\subsection{Conclusion}

At this age and time professional training of members is to be a priority for the leadership. This is because of the big challenge of sustainability of institutes of consecrated life. There is urgent need for it to be seriously looked into.

\section{References}

[1] Armstrong, M. (2016). Armstrong's handbook of strategic human resource management, $\left(6^{\text {th }}\right.$ ed.) New York: Kogan

[2] Armstrong, Michael. (2009). Armstrong's handbook of human resource management practice. Kogan page: London.

[3] Adhiambo, J. M. (2009). Educational Administration. Nairobi: CUEA Press

[4] Best, J. W., \& Kahn, J. V. (2005). Research in Education (10 ${ }^{\text {th }}$ ed.). New Jersey: Prentice

[5] Boxall, P. (2013) Mutuality in the management of human resources: Assessing the quality of alignment in employment relationships. Human Resource Management Journal, 23(1), 3-17.

[6] Boxall, P. (2014). The future of employment relations from the perspective of human resource management. Journal of Industrial Relations, 56(4), 578-593.

[7] Chandran, E. (2004). Research methods: A quantitative approach with illustrations from Christian ministries. Nairobi: Daystar University.

[8] D'Souza, A. (2014). Leadership: A trilogy on leadership and effective management. Nairobi: Paulines Publications Africa.

[9] D'Souza, A. A. (2001). Leaders for today hope for tomorrow. Empowering and empowered ledearship. Paulines Publications Africa: Nairobi, Kenya.

[10] Dessler, Gary. (2003). Human resource management. Delhi: Pearson Education.

[11] Ivancevich, J. M., Matteson, M. T. \& Konopaske, R. (2011). Organizational behavior \& management. Boston: McGraw-Hill/Irwin

[12] Johnson, B., \& Christensen, L. (2012). Educational research: Quantitative, qualitative, and mixed approaches. Los Angeles: SAGE.

[13] Kothari, C. R. (2004). Research methodology: Methods and techniques ( $2^{\text {nd }}$ Revised ed.). New Delhi: New Age International (P) Limited, Publishers.

[14] Krejcie, R. V., \& Morgan, D. W. (1970). Determining sample size for research activities. Educational and Psychological Measurement, 30, 607- 610.

[15] Kyalo, B. (2017). An experience of Religious Life in the $21^{\text {st }}$ Century: A Journey of Faith, Joy and Love. Nairobi: CUEA Press.

[16] Lodico, M. G., Spaulding, D. T., \& Voegtle, K. H. (2010). Methods in educational research: From theory to practice. San Francisco: Jossey-Bass

[17] Mattam, J. (1994). Religious life: Within a Christian vision of reality. Anand: Gujarat Sahitya Prakash.

[18] Njino, J. K. (2009). Resource management for sustainable development in the church. Eldoret, Kenya: AMECEA Gaba Publications.

[19] Okumbe, J. A. (2001). Human resource management. Nairobi: Educational Development and Research Bureau.

[20] Okumbe, J. A. (2007). Educational management: Theory and practice. Nairobi: Oxford University Press. 
[21] Oso, W. Y \& Onen, D. (2009). Agenral guide in writing research proposal and report: A handbook for beginning researchers. Nairobi: Jomo Kenyatta Foundation.

[22] Robson, C. (2002). Real world research ( $2^{\text {nd }}$ ed.). Malden: Blackwell Publishing.

[23] Signh, Y. K., \& Nath, R. (2007). Research methodology. New Delhi: S. B. Nangia APH Publishing Corporation.

[24] Teklemariam, A. A. (2009). Human Resource Management for Educational Practitioners in Africa. Nairobi: CUEA Press

[25] Teklemariam, A. A. \& Nam, P. A. O. (2011). Educational Planning for Educational Planners, Managers, and Student-Teachers in Africa. Nairobi: CUEA Press

[26] Tangaza University College. (2017) Statistics of the number Congregations. Registry

[27] Marist International University College. (2017). Statistics of the number Congregations. Registry

[28] Waweru, M. (2007). Management of human resources in Kenya. Nairobi: Kenya Literature Bureau.

\section{APPENDICES}

\section{APPENDIX I: QUESTIONNAIRE FOR INDIVIDUAL MEMBERS}

P.O BOX 24557- Nairobi, 00502, Karen

Phone: +254 727527746

Email: jackalari@gmail.com

Dear Participant,

The purpose of the study is to gather data on leadership and management of the human resource in institutes of consecrated life in the Catholic Archdiocese of Nairobi, Kenya. Therefore, you are deemed important to be in a position to provide honest, factual and relevant information on what happens and your feelings about these.

Please note that the information you give will be treated with utmost confidence and used only for the purpose of this research.

\section{Instructions:}

- Please put a tick in one of the box with an option you consider most appropriate in each question.

- When an explanation is required use the space provided

Yours faithfully,

Okello Jacklyne Alari

Researcher

\section{SECTION A: BACKGROUND INFORMATION}

1. Which category of the institute of consecrated life do you belong?

\section{Men religious [ ] Women religious [ ]}

2. How long have you been a member of your institute

\section{0- 5 years [ ] 6-10 years [ ] 11-15 years[ ] 16-20years [ ] Above 20years [ ]}

\section{SECTION B: TRAINING AND DEVELOPMENT OF THE MEMBERS}

3. Does the leadership offer equal training opportunities for its members? Yes ( ) No ( )

4. Do you think that the leadership trains members in the light of their gifts and talents?

Yes ( ) No ( )

Explain your answer 
5. In your opinion do you think training of the members is important?

Why?

Please indicate with a ( ) whether you either strongly agree (SA), agree (A), disagree (D) or strongly disagree (SD) with the following statements

\begin{tabular}{|c|c|c|c|c|}
\hline Statement & SA & $\mathbf{A}$ & $\mathbf{D}$ & SD \\
\hline 6. My congregation have training policies for the members & & & & \\
\hline $\begin{array}{l}\text { 7. All members have the opportunity of spiritual training and } \\
\text { development }\end{array}$ & & & & \\
\hline $\begin{array}{l}\text { 8. Professional training of members is a priority for the } \\
\text { leadership }\end{array}$ & & & & \\
\hline $\begin{array}{l}\text { 9. All members have equal opportunity for professional training } \\
\text { and development }\end{array}$ & & & & \\
\hline $\begin{array}{l}\text { 10. The leadership ensures that all professionally trained } \\
\text { members are engaged in sustainable apostolates to support the } \\
\text { community and congregation }\end{array}$ & & & & \\
\hline $\begin{array}{l}\text { 11. Professionally trained members in my congregation earn } \\
\text { sufficient to sustain the community and congregation }\end{array}$ & & & & \\
\hline $\begin{array}{l}\text { 12. Majority of professionally trained members leave the } \\
\text { congregation as soon as they complete their courses }\end{array}$ & & & & \\
\hline
\end{tabular}

\section{SECTION C: SELECTION AND PLACEMENT}

13. Do you think in the appointment and placement of members the leadership is focused on sustainable development of the congregation? Yes ( ) No ( )

Explain your answer above

14. The leadership commissions members for apostolate depending on the individual's ability and talent

$$
\text { Yes ( ) No( ) }
$$

15. Do you think the leadership harnesses the human potential for sustainable development in your congregation? Yes ( )

No ( ) 
Please indicate with a ( ) whether you either strongly agree (SA), agree (A), disagree (D) or strongly disagree (SD) with the following statements

\begin{tabular}{|c|c|c|c|c|}
\hline Statement & SA & $\mathbf{A}$ & D & SD \\
\hline $\begin{array}{l}\text { 16. The leadership has designed orientation programmes for all } \\
\text { members while taking up tasks within the congregational } \\
\text { projects }\end{array}$ & & & & \\
\hline $\begin{array}{l}\text { 17. When appointing members for apostolate the leadership } \\
\text { provides them with details of the task descriptions and the } \\
\text { overall expectations of work related activities. }\end{array}$ & & & & \\
\hline $\begin{array}{l}\text { 18. The leadership gives members opportunities for on-the-job } \\
\text { training }\end{array}$ & & & & \\
\hline $\begin{array}{l}\text { 19. The leadership gives members opportunities for off-the-job } \\
\text { training }\end{array}$ & & & & \\
\hline $\begin{array}{l}\text { 20. The leadership encourages members to learn from each other } \\
\text { as they work together. }\end{array}$ & & & & \\
\hline
\end{tabular}

\section{SECTION D: MEMBERS MOTIVATION}

21. Are you sufficiently motivated by the leadership as a member of your congregation?

Yes ( ) No ( )

22. What motivational techniques does the leadership use for the members?

23. How are you motivated by the leadership in your apostolate?

Please indicate with a ( ) whether you either strongly agree (SA), agree (A), disagree (D) or strongly disagree (SD) with the following statements

\begin{tabular}{|c|l|l|l|l|}
\hline Statement & SA & A & D & SD \\
\hline $\begin{array}{l}\text { 24. The leadership often visits members in their places of } \\
\text { apostolates for encouragement }\end{array}$ & & & \\
\hline $\begin{array}{l}\text { 25. The leadership only visits members in their place of } \\
\text { apostolate to solve conflicts }\end{array}$ & & & \\
\hline
\end{tabular}




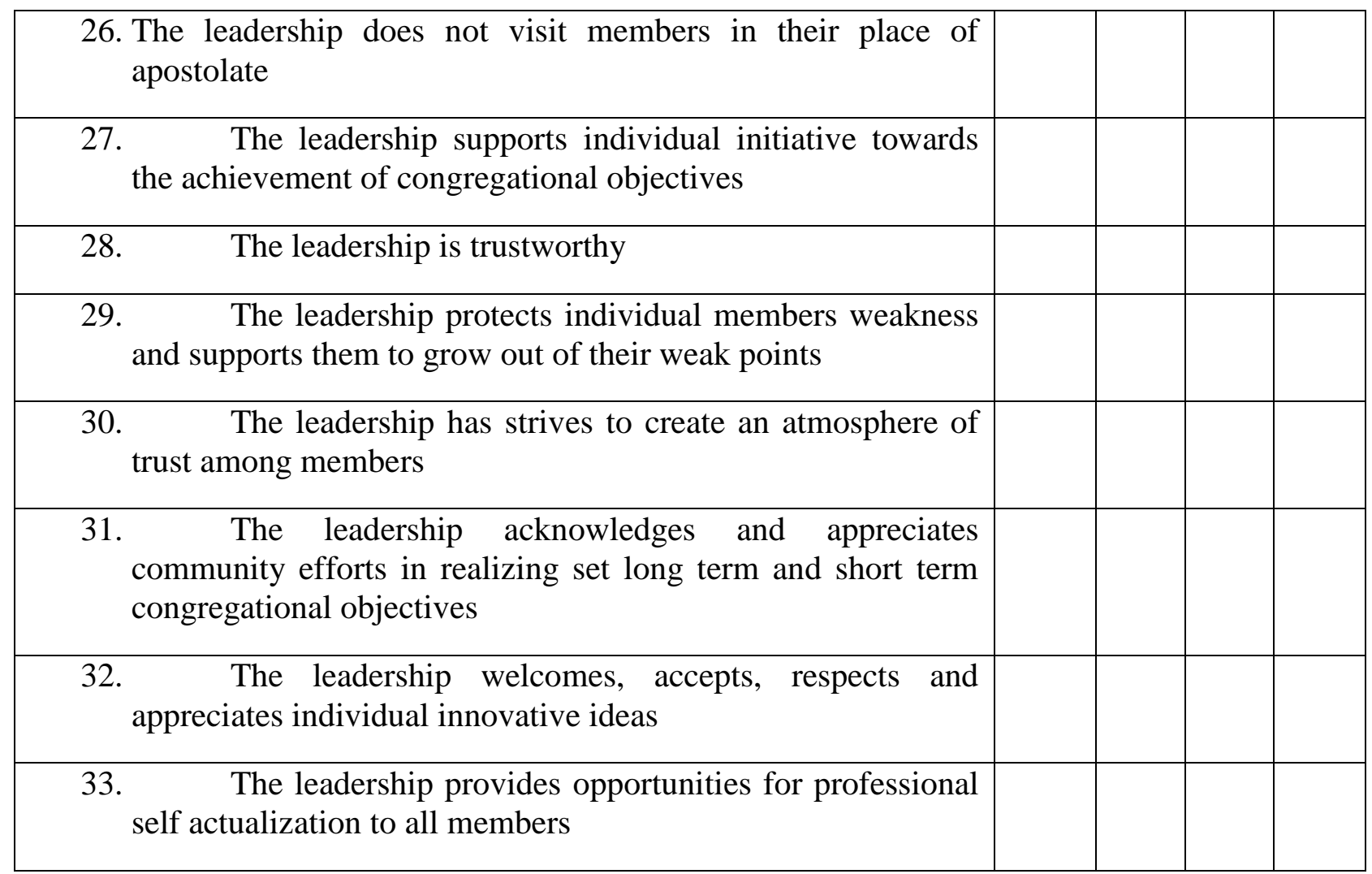

\section{APPENDIX II: QUESTIONNAIRE FOR THE REGIONAL, PROVINCIAL AND GENERAL SUPERIORS}

P.O BOX 24557- Nairobi, 00502, Karen

Phone: +254 727527746

Email: jackalari@gmail.com

Dear Participant,

The purpose of the study is to gather data on leadership and management of the human resource in institutes of consecrated life in the Catholic Archdiocese of Nairobi, Kenya. Therefore, you are deemed important to be in a position to provide honest, factual and relevant information on what happens and your feelings about these.

Please note that the information you give will be treated with utmost confidence and used only for the purpose of this research.

\section{Instructions:}

- Please put a tick in one of the box with an option you consider most appropriate in each question.

- When an explanation is required use the space provided

Yours faithfully,

Okello Jacklyne Alari

Researcher

SECTION A: Background Information

1. Which category of the institute of consecrated life do you belong?

Men religious [ ] Women religious [ ]

2. How long have you been a member of your institute

0 - 5 years [ ] 6-10 years [ ] 11-15 years [ ] 16-20years [ ] Above 20years [ ]

SECTION B: TRAINING AND DEVELOPMENT OF THE MEMBERS

3. Do you offer equal training opportunities for your members? Yes ( ) No ( ) 
4. From your observation do you appreciate the unique gifts and talents of each member? Yes ( ) No ( )

5. Do you think you take members for training in the light of their gifts and talents?

Yes ( ) No ( )

Explain your answer

6. In your opinion do you think training of the members is important?

Why?

7. Do you ensure that the appointment and placement of members is focused on sustainable development of the congregation?

Yes No

Explain your answer

Please indicate with a ( ) whether you either strongly agree (SA), agree (A), disagree (D) or strongly disagree (SD) with the following statements

\begin{tabular}{|c|c|c|c|c|}
\hline Statement & SA & $\mathbf{A}$ & $\mathbf{D}$ & SD \\
\hline 8. My congregation have training policies for the members & & & & \\
\hline $\begin{array}{l}\text { 9. All members have the opportunity of spiritual training and } \\
\text { development }\end{array}$ & & & & \\
\hline 10. Professional training of members is our priority & & & & \\
\hline $\begin{array}{l}\text { 11. All members have opportunity for professional training } \\
\text { and development }\end{array}$ & & & & \\
\hline $\begin{array}{l}\text { 12. We ensure that all professionally trained members are } \\
\text { engaged in sustainable apostolates to support the } \\
\text { community and congregation }\end{array}$ & & & & \\
\hline $\begin{array}{l}\text { 13. Professionally trained members in my congregation earn } \\
\text { sufficient to sustain the community and congregation }\end{array}$ & & & & \\
\hline $\begin{array}{l}\text { 14. Majority of professionally trained members leave the } \\
\text { congregation as soon as they complete their courses }\end{array}$ & & & & \\
\hline
\end{tabular}

\section{SECTION C: SELECTION AND PLACEMENT}

15. Do you allot work and provide job satisfaction to members according their skills, knowledge and need? Yes ( ) No( )

Explain your answer above 
16. Do you commission members for apostolate depending on the individual's ability and talent? Yes ( ) No( )

17. Do you harness the human potential for sustainable development of the congregation? Yes ( ) No ( )

Explain your answer

Please indicate with a ( ) whether you either strongly agree (SA), agree (A), disagree (D) or strongly disagree (SD) with the following statements

\begin{tabular}{|c|c|c|c|c|}
\hline Statement & SA & $\mathbf{A}$ & $\mathbf{D}$ & SD \\
\hline $\begin{array}{l}\text { 18. The leadership has designed orientation programmes for } \\
\text { all members while taking up tasks within the } \\
\text { congregational projects }\end{array}$ & & & & \\
\hline $\begin{array}{l}\text { 19. When appointing members for apostolate the leadership } \\
\text { provides them with details of the task descriptions and the } \\
\text { overall expectations of work related activities. }\end{array}$ & & & & \\
\hline $\begin{array}{l}\text { 20. The leadership gives members opportunities for on-the-job } \\
\text { training }\end{array}$ & & & & \\
\hline $\begin{array}{l}\text { 21. The leadership gives members opportunities for off-the- } \\
\text { job training }\end{array}$ & & & & \\
\hline $\begin{array}{l}\text { 22. The leadership encourages members to learn from each } \\
\text { other as they work together. }\end{array}$ & & & & \\
\hline
\end{tabular}

\section{SECTION D: MEMBERS MOTIVATION}

23. What motivational techniques do you use for the members?

24. How do you motivate members in their apostolate?

Please indicate with a ( ) whether you either strongly agree (SA), agree (A), disagree (D) or strongly disagree (SD) with the following statements

\begin{tabular}{|c|l|l|l|l|}
\hline Statement & SA & A & D & SD \\
\hline $\begin{array}{c}\text { 25. The leadership often visits members in their places of } \\
\text { apostolates for encouragement }\end{array}$ & & & \\
\hline
\end{tabular}




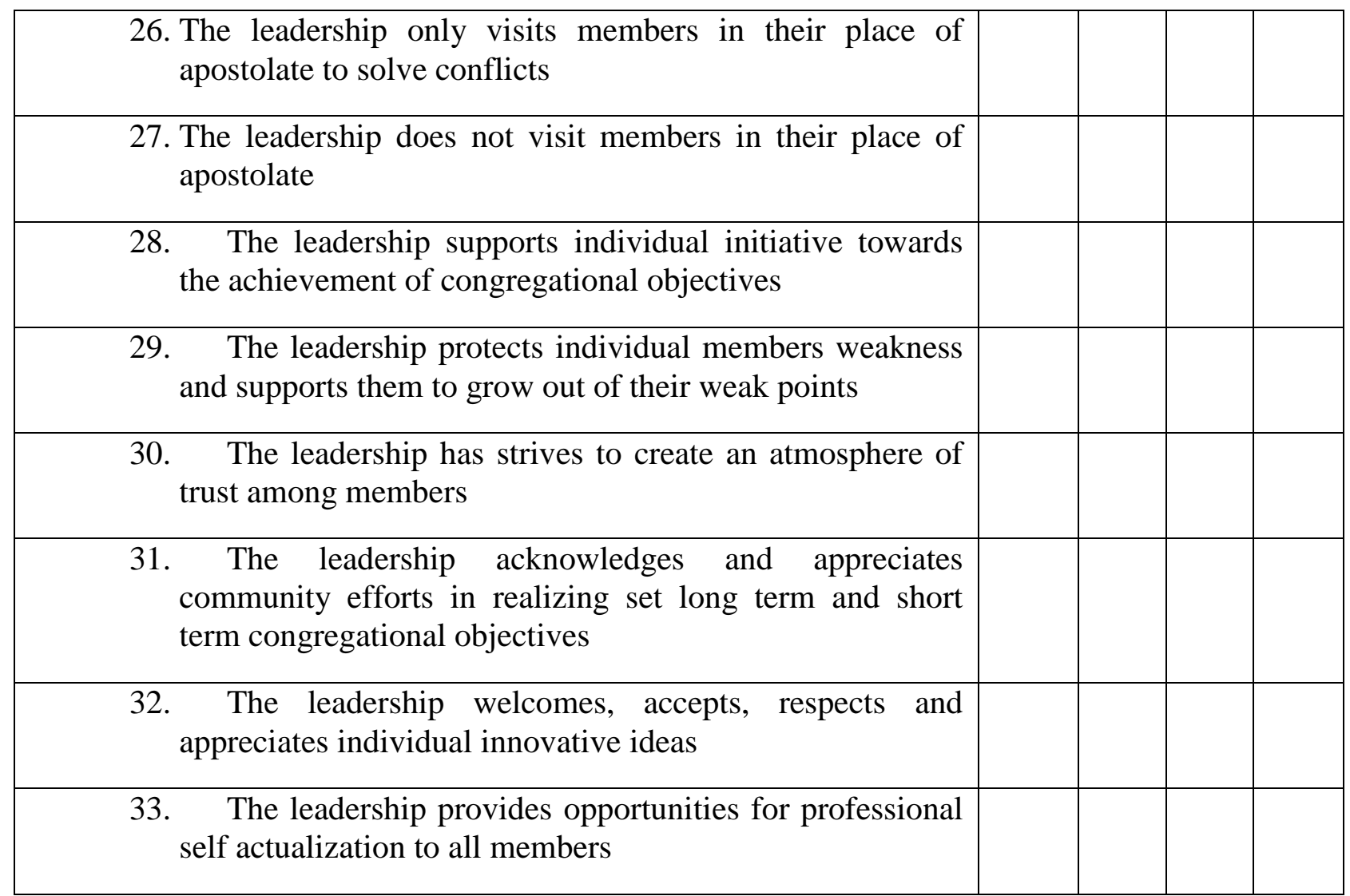

\section{APPENDIX III: One-way ANOVA and One Sample T-Test Analysis for $\mathbf{H}_{01}$}

There is no significant relationship between category of the institute and availability of training policies of the human resource in institutes of consecrated life.

One-way

ANOVA
My congregation has training policy for members
\begin{tabular}{|l|r|r|r|r|r|}
\hline & Sum of Squares & Df & Mean Square & F & Sig. \\
\hline Between Groups & 5.299 & 1 & 5.299 & 6.481 & .012 \\
Within Groups & 188.076 & 230 & .818 & & \\
Total & 193.375 & 231 & & & \\
\hline
\end{tabular}

\section{T-Test}



One-Sample Test

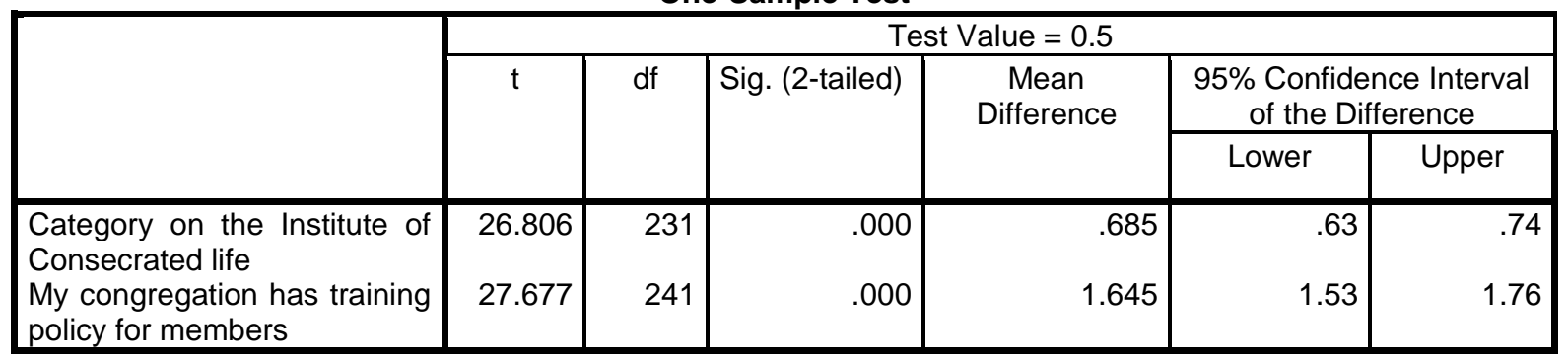




\section{APPENDIX IV: One-way ANOVA Analysis for $\mathrm{H}_{02}$}

There is no significant relationship between category of the institute and commissioning of members by the leadership in the light of the individual's ability and talent.

\section{One-way}

\section{ANOVA}

Do you commission members for apostolate depending on the individual's ability and talent

\begin{tabular}{|l|r|r|r|r|r|}
\hline & Sum of Squares & df & Mean Square & F & Sig. \\
\hline Between Groups & .200 & 1 & .200 & .750 & .398 \\
Within Groups & 4.800 & 18 & .267 & & \\
Total & 5.000 & 19 & & & \\
\hline
\end{tabular}

\section{ANOVA}

The leadership commissions members for apostolate depending on the individual's ability and talent

\begin{tabular}{|l|r|r|r|r|r|}
\hline & Sum of Squares & df & Mean Square & F & Sig. \\
\hline Between Groups & 2.307 & 1 & 2.307 & 9.575 & .002 \\
Within Groups & 52.529 & 218 & .241 & & \\
Total & 54.836 & 219 & & & \\
\hline
\end{tabular}

\section{APPENDIX V: One-way ANOVA Analysis for $\mathbf{H}_{03}$}

There is no significant relationship between category of the institute and practical motivational approaches used by the leadership in institutes of consecrated life.

One-way

ANOVA

Does the leadership motivate members in their apostolate

\begin{tabular}{|l|r|r|r|r|r|}
\hline & Sum of Squares & df & Mean Square & F & Sig. \\
\hline Between Groups & .875 & 1 & .875 & 4.453 & .036 \\
Within Groups & 44.192 & 225 & .196 & & \\
Total & 45.066 & 226 & & & \\
\hline
\end{tabular}

ANOVA

The leadership often visits members in their places of apostolate for encouragement

\begin{tabular}{|l|r|r|r|r|r|}
\hline & Sum of Squares & \multicolumn{1}{|c|}{$\mathrm{df}$} & Mean Square & $\mathrm{F}$ & Sig. \\
\hline Between Groups & 4.164 & 1 & 4.164 & 6.071 & .014 \\
Within Groups & 157.750 & 230 & .686 & & \\
Total & 161.914 & 231 & & & \\
\hline
\end{tabular}

ANOVA

The leadership supports individual initiative towards the achievement of congregational objectives

\begin{tabular}{|l|r|r|r|r|r|}
\hline & Sum of Squares & df & Mean Square & F & Sig. \\
\hline Between Groups & .529 & 1 & .529 & .731 & .393 \\
Within Groups & 166.432 & 230 & .724 & & \\
Total & 166.961 & 231 & & & \\
\hline
\end{tabular}

